\title{
IMPACT ANALYSIS OF EQUITY VARIATION ON THE FINANCIAL POSITION OF THE ECONOMIC ENTITY
}

\author{
Nicolae Balteș ${ }^{1}$ \\ Alina Teodora Ciuhureanu ${ }^{2}$
}

ABSTRACT: The analysis of equity and their variation during a financial year is an old custom in Anglo-Saxon accounting. In its simple form, such an analysis can be found in the interpretation of the structure ,accumulated and retained situation” from North-American practices. Changes in the company's equity occurred between two dates of the balance sheet reflect the increase or decrease of net assets or of the wealth during the exercise. With the exception of changes resulting from transactions with the owners, such as contributions/withdrawals of capital and the distribution of dividends, the global modification of equity is represented by total earnings and losses generated by the activities carried out by the company during the entire reference period.

Key words: equity, physical capital, financial capital, maintaining the capital.

JEL Codes: G30, G32

\section{Introduction}

In business or economics, the world of capital has two distinct meanings. Businessmen consider the capital as the amount of money that is used to do business, the lucrative capital. Economists sometimes define capital as "durable goods" which cause a flow of services in time. The capital can also be defined as a set of heterogeneous and reproducible economic resources that, through indirect usage, enable obtaining an income (Sandu, 2000: 24). Basically, capital is any type of wealth used for the production of a bigger wealth for the company (Ciuhureanu, 2009: 63).

\section{Conceptual delimitations regarding the company's equity}

Equity is the shareholders' residual interest in the assets of a company after deducting all its liabilities. There are however two very important concepts regarding capital (International Standards for Financial Reporting issued on January, $1^{\text {st }}$ 2011, part A, A50-A51) that should be considered:

- The financial concept of capital (the owners' capital), adopted by most companies in the elaboration of the financial statements and which is synonym to the net assets or with equity. It can be expressed as the money invested or the invested purchasing power. This proves appropriate when the users of accounting information have as main concern to maintain the nominal invested capital or the purchasing power of the invested capital.

- The physical concept of capital (the company's capital) represents the company's production capacity, expressed, for example, in daily production units. This demonstrates its utility if it is used in situations where the main concern of the beneficiaries of accounting information is represented by the operating capacity of the company.

Given these limitations it is considered that the selection of the most appropriate concept regarding the capital should be based on the need to meet the requirements of the users of financial situations, which is why it is considered that adopting the concept of financial capital is required when they are interested mainly in the maintenance of the nominal invested capital, while the

\footnotetext{
1 "Lucian Blaga"University of Sibiu, România,e-mail: baltes_n@yahoo.com

2 "Româno-Germană" University of Sibiu, Romania,e-mail: alinaciuhureanu@yahoo.com
} 
notion of physical capital is used if the main concern of the users is to maintain the operating capacity of the company (Brabete; Drăgan, 2004: 25).

Regardless of the type and size of the company, the equity determines the legal establishment of the company.

Equity is a permanent funding of the company and it includes the following elements: registered capital, bonus shares, re-evaluation reserves, reported result, the result of the exercise.

It can be noticed that, as compared to the establishment sources, equity can be:

a) Equity contribution (registered capital), representing the nominal value of shares, i.e. the amount of in-kind and/or cash contribution, integral arrearage, profit distributed for the increase of capital or for other operations that lead to its modification. It takes the form of subscribed and unpaid capital and subscribed and paid capital.

For the establishment of joint stock companies, at least $30 \%$ of the subscribed capital must be paid. The remaining capital will be paid within 12 months from registration to the Trade Registry for cash contribution and within 2 years for in-kind contribution (Law no. 31/ 1990).

Companies with limited liability, partnerships and limited partnerships must pay the whole subscribed capital at the date of establishment.

If the company is sole shareholder, the in-kind contribution amount will be established based on a specialised expertise (Law no. 31/ 1990).

Any changes in the registered capital may only occur based on a decision of the general meeting of shareholders or members and with the fulfilment of all legal requirements regarding this decision.

The minimum size of registered capital depends on the type of company, as follows:

- $\quad$ For the companies in partnership and limited partnership, there is not a minimum capital;

- $\quad$ For the joint stock companies, the minimum registered capital is 90.000 lei, but not less than 25.000 euro in lei, and the minimum nominal value of a share is 0,10 lei (Law no. 31/ 1990);

- $\quad$ For the companies with limited liability the minimum registered capital is 200 lei and is divided in equal shares whose nominal value cannot be less than 10 lei (Law no. 31/ 1990);

- Joint stock companies must have at least two shareholders and the limited liability company can have up to 50 partners (Law no. 31/ 1990).

The need to increase the registered capital may occur when the economic entity has financial difficulties but also when it is prosperous but wants to extend its activity. In both cases, the enterprise needs additional financial resources or certain goods, preferring to obtain them by increasing the capital to the detriment of relying on loans, which involves a significant financial effort (Pântea, Bodea, 2011: 380). The increase of registered capital can be achieved in several ways, such as:

- Through in-kind or cash contributions. The purpose of increasing the registered capital through new contributions is to attract additional financial resources for financing investment operations or strengthening the financial situation.

- Through internal operations, i.e. the inclusion of some elements of equity, such as: arrearage (except the statutory reserves), bonus shares, profit.

- $\quad$ Through the conversion of debts in shares. This operation leads to the cancellation of certain debts of the company without being forced to resort to cash. Debts turn into shares only through the consent of the creditor who thus becomes shareholder or partner. The nominal value of convertible bonds into shares must be equal to that of the shares.

The most common situations requiring the reduction of registered capital are:

- Covering losses from previous financial years, provided that it is noticed that they cannot be covered from the reserves or profits of future financial years; 
- The existence of an oversized registered capital in relation to the economic activity of the entity;

- Retirement of some partners or shareholders, to whom the counter value of their contribution is returned.

Reduction of registered capital can be achieved either through the reduction of the nominal value or of the number of shares, or by redemption of and then cancellation of own shares.

b) Bonus shares, representing the excess between the issue value and the nominal value of shares and they are grouped into:

- The share premium is determined as the difference between the price for issue of new shares and their nominal value.

- The merger premium is determined as the difference between the value of the contribution resulting from the merger and the value by which it increased the registered capital of the absorbing company.

- The bonus share is calculated as the difference between the value of the goods brought and the nominal value of the registered capital that these contributions have been paid with.

- The conversion premium of bonds into shares is calculated as the difference between the nominal value of bonds corresponding to the bond credits and the value of issued shares according to the contractual stipulations, when the value of the bonds is higher than the value of the corresponding shares.

c) Reserves from re-evaluation ,are the pluses and minuses of value resulting from the reevaluation of assets, usually of tangible assets" (Pântea, Bodea, 2011: 392). Arrearage from reevaluation is calculated as the difference between the fair value and the net book one.

- The net book value of an asset is the carrying amount (of the input) minus the adjustments for depreciation of that asset.

- The fair value (present value) is the amount for which an asset can be traded or a liability settled. Usually, the present value is calculated by a qualified evaluation specialist, member of a professional body in the field.

Reserves from re-evaluation are calculated only if the increase or decrease in value is considered safe and durable.

During re-evaluation, accumulated depreciation on tangible assets may be:

- $\quad$ Recalculated proportionately with the change of gross carrying amount, so that the updated book value is equal to the revaluated value (fair value);

- $\quad$ Eliminated from the gross carrying amount, so that the updated net carrying amount is equal to the revaluated value (fair value).

If the result of the evaluation is an increase from the net carrying amount then it is treated as an increase of the re-evaluation reserve, if there had not been a previous decrease recognised as an expense of that asset or as an income that would compensate the expense with the previously recognised decrease of that asset.

If the result of the re-evaluation is a decrease of the net carrying amount, then it is treated as an expense with the entire amount of depreciation, if there is not registered in the re-evaluation reserve a surplus from re-evaluation or a decrease of the re-evaluation reserve by the minimum between the amount of that reserve and the amount of the decrease and the potential difference remained uncovered is registered as an expense.

No part of the re-evaluation reserves can be distributed directly or indirectly, unless the revaluated asset was capitalised, which means the surplus from re-evaluation is actual realised earnings. The gain is considered realised when the asset for which the re-evaluation reserve was made is removed. Also, part of the gain can be realised as the asset is used by the company. In this case, the value of the reserve transferred is the difference between the redemption calculated based 
on the revaluated carrying amount and the amount of the redemption calculated based on the original cost of the asset.

d) Reserves. Their creation and usage are particular aspects from one category to another of reserve, with (Balteş, Ciuhureanu, 2009: 105-106):

- Legal reserves that are currently establishing at the end of the financial year from the gross profit at a rate of $5 \%$ until they reach 20 or $25 \%$ of the registered capital, as the company has national or mixed capital. These reserves cannot be used to increase the registered capital, to cover losses from previous financial years or to cover current losses;

- Statutory or contractual reserves that are deposited annually from the company's net profit, according to the stipulations of its articles of association;

- Reserves representing the surplus from re-evaluation reserves established while revaluated assets are depreciated or when they are sold or annulled.

- Other reserves that can be created optionally from the net profit and that are used to cover some losses from the repurchase of own shares, payment of dividends in the financial years that ended in losses, increase of registered capital etc.

e) Results carried forward refer to the result or a part of the previous years, materialised in profit or loss, whose distribution or coverage had been postponed by the shareholders' or partners' general assembly. The profit carried forward leads to the increase of own capital and the loss carried forward results in their reduction (Balteş, Ciuhureanu, 2009: 105-106)

f) The result of the financial year (profit or loss) is calculated as the difference between total income and expenses of the company.

The profit (or loss) of the financial year should be cumulated from the beginning of the financial year, after closing the income and expenses accounts. Incomes are transferred in account credit 121 "Profit and loss", and expenses in account debit 121 "Profit and loss". If, at the end of the financial year, the account has a credit balance, it means that the company has had profit and if there is an overdraft account, then the company has had losses from its activity. By deducting the tax on profit from the balance profit, the net profit results, which is the subject of the distribution on destinations, such as:

- Provisioning reserves under the limits established by law;

- Covering losses from previous years;

- Establishing the profit participation fund for employees;

- Increasing own funding resources;

- Dividends due to shareholders or partners; etc. (Balteş, Ciuhureanu, 2007: 29)

The possible loss recorded at the end of the financial year shall be covered from the result carried forward and the financial result of future financial years; decrease of equity capital, reserves and/or bonus shares; decrease of other own funding sources.

\section{Evaluation of securities}

There are many forms of the value of shares: the nominal value, market value, price of issue, financial value, turnover value, accounting value etc.

The nominal value is the value stipulated in the articles of association and written on the securities, either shares, or shares in the formation of the company. It is determined as the relation between the registered capital value and the number of securities issued. The market value is the sale-purchase value of the securities which is usually established through negotiation on the stock market, based on the relation between demand and offer. The market price of a share depends on many factors, such as:

- The size of the shares expected by shareholders;

- The financial stability of the entity;

- General situation of the capital market; 
- Interest rate; etc.

The price of issue (the share's rate) is the price that must be paid by those who subscribe to shares. The price of issue may be equal or higher than the nominal value.

The financial value represents the equivalent of the annual dividend capitalization for one share at an average interest rate on the market.

The turnover value is the value of the net profit for a share which could be capitalized during the financial year at an average interest rate on the market. The income of the securities is equal to the value of dividends plus the profit incorporated in reserves.

The carrying amount (from the balance-sheet) is determined as the ratio between the net accounting asset and the number of securities.

\section{Objectives of the analysis on equity fluctuation}

A key issue concerns the capital maintenance concept, referring both to the financial capital and the physical one. This takes into consideration the way in which accountancy defines the capital that the company wants to maintain, linking the concepts of capital and profit because it provides the reference point without which profit cannot be measured. Therefore, maintaining the financial capital refers to the situation in which profit is not obtained unless the financial value (or monetary) of net assets, established at the end of the financial year, is higher than that established at the beginning of the year, after all distributions to shareholders and all contributions from shareholders during the analysed period having previously been excluded. Maintaining the physical capital requires that the profit is obtained only when the physical production capacity (or the operating capacity) of the company (or the resources, respectively the money needed to achieve that capacity) exceeds, at the end of the period, the productive physical capacity from the beginning of the period after all distributions to shareholders and all contributions from shareholders during the analysed period having previously been excluded.

Basically, the change in equity is a separate component of the financial statements and it outlines:

- The net profit or the net loss of the period and the influence on equity;

- Capital transaction with shareholders and distributions to them;

- Changes in equity at the beginning and end of the period.

Under these circumstances, as separate component of the financial statements, we consider that nowadays the situation of changes in equity presents in detail all fluctuations that the net asset (equity) met from the beginning to the end of the financial year. This document is established as an informational basis for the analysis of the capital's maintenance capacity (or erosion), as well as the general profit or loss of the company. Changes in equity occurred between the two dates of the balance sheet reflect the increase or reduction of the net asset or of the wealth during the financial year. With the exception of changes resulting from transactions with shareholders, such as the contributions/withdrawals of capital and the distribution of dividends, the global change of equity represents the total gains and losses generated by the activities carried out by the company during the reference period. Given these notions and the possibility to choose, so that information is relevant, the accounting information system is required to find a balance between relevance and reliability, each of the situations presented having different contributions in this regard.

Study on the fluctuation analysis of equity of a company at the end of the financial year

Our research was conducted based on data supplied by the financial statements of Compa SA Sibiu, a company quoted on the Bucharest Stock Exchange, category II, having the CMP symbol (www.bvb.ro). The economic entity is headquartred in Sibiu and its main business activity is the „Manufacturing of parts and accessories for motor vehicles and motor vehicle engines”, code 
CAEN 2932. Table 1 below shows the development of equity and its components during the financial year 2011.

Table no. 1

Evolution of equity during a financial year

\begin{tabular}{|c|c|c|c|c|}
\hline Elements of the equity & $\begin{array}{c}\text { Balance } \\
\text { account at } \\
01.01 \text { an } 2011\end{array}$ & Increases & Decreases & $\begin{array}{l}\text { Balance account } \\
\text { at } 31.12 \text { an } 2011\end{array}$ \\
\hline 0 & 1 & 2 & 3 & $4=1+2-3$ \\
\hline Subscribed and paid equity & 21.882 .104 & - & - & 21.882 .104 \\
\hline $\begin{array}{l}\text { Reserves from the re- } \\
\text { evaluation of assets }\end{array}$ & 204.710 .356 & - & 2.351 .404 & 202.358 .952 \\
\hline $\begin{array}{l}\text { Reserves representing the } \\
\text { surplus made from re- } \\
\text { evaluation reserves }\end{array}$ & 4.590 .313 & 2.351 .404 & - & 6.941 .717 \\
\hline Legal reserves & 3.499 .329 & 877.091 & - & 4.376 .421 \\
\hline Other reserves & 31.655 .695 & 8.826 .110 & - & 40.481 .806 \\
\hline $\begin{array}{l}\text { Results carried forward } \\
\text { representing the retained } \\
\text { earnings or the uncovered loss }\end{array}$ & 29.144 & - & - & 29.144 \\
\hline Result of the current financial & 9.515 .839 & 17.369 .837 & 9.515 .839 & 17.369 .837 \\
\hline Distribution of profit & -689.728 & -877.091 & -689.728 & -877.091 \\
\hline Total equity & 275.193 .053 & 28.547 .352 & 11.177 .515 & 292.562 .890 \\
\hline
\end{tabular}

From the situation presented above, it can be noticed that during the financial year, equity (net asset) of the company has increased from 275.193.053 lei at the beginning of the financial year to $292.562 .890 \mathrm{lei}$, at the end of the financial year, i.e. with the total amount of 17.369.837 lei.

A significant contribution to this increase was represented by the year's net profit, which in 2011 recorded an increase of 7,853,998 lei (representing 82.53\%) as compared to the previous financial year. The other components of equity contributed to its increase as follows:

During the analysed financial year, the subscribed and paid equity has not increased, therefore remaining within the same values.

- The company has not made the re-evaluation of assets during the analysed financial year. Instead, the subtraction from evidence of certain tangible assets completely depreciated, reevaluated in the previous financial years, led to the decrease by 2.351 .404 lei of re-evaluation reserves, amount that has capitalised through the transfer to "Reserves from the surplus made from re-evaluations", according to OMFP 3055/2009, as amended and supplemented, their amount increasing to 6.941 .717 lei.

- Legal reserves of the company increased at the end of the financial year to 877.091 lei, by allocating the 5\% rate of the gross profit, according to art. 247 (2) of OMFP 3055/2009, as amended and supplemented.

- Other reserves, made from the net profit of the company increased from 31.655.695 lei at the beginning of the financial year, to 40.481 .806 lei at the end of the financial year, therefore with 8.826.110 lei, following the decision of the Shareholders' General Assembly to distribute all net profit to increase the company's own financing sources.

- The result carried forward of the company from previous financial years has not changed in the current financial year.

The equity increase during the financial year 2011led to changes in the company's financial situation (Table 2). 
Evolution of indicators regarding the financial situation

Table no.2.

\begin{tabular}{|l|l|r|r|r|}
\hline $\begin{array}{l}\text { Nr. } \\
\text { crt. }\end{array}$ & \multicolumn{1}{|c|}{ Indicators } & Year 2010 & Year 2011 & \multicolumn{1}{|c|}{ Deviations (+-) } \\
\hline 1 & Current ratio & 148,72 & 164,23 & $+15,51$ \\
\hline 2. & Solvency ratio & 58,51 & 59,31 & $+0,8$ \\
\hline 3. & Return on capital employed & 3,77 & 5,91 & $+2,14$ \\
\hline 4. & Global gearing ratio & 40,54 & 35,85 & $-4,69$ \\
\hline
\end{tabular}

Source: Authors' own calculations based on the Annual financial information of Compa SA Sibiu during the 20102011 period, www.bvb.ro

We can see an improvement in the economic entity's financial situation from one financial year to another, expressed as liquidity, solvency, return and risk ratios. Thus, as compared to the previous financial year, there is a $15.51 \%$ increase in liquidity, a $0.8 \%$ increase in solvency and a $2.14 \%$ increase in return, while indebtedness decreased by $4.69 \%$.

\section{Conclusions}

During the analysed financial year the company recorded a consolidation of its financial standing, materialized as a significant increase in its own financial resources. An important contribution to this increase was represented by the net profit for the year, which in 2011 saw an increase of 7,853,998 lei ( representing 82.53\%) against the previous financial year. The financial capital maintenance favourably influences indicators of liquidity, solvency and the return of employed capital, as well as the decrease in the gearing ratio and the economic entity' dependence on third parties.

\section{References}

1. Balteş N., 2010. Analiză şi diagnostic financiar, Publishing House of the „Lucian Blaga” University of Sibiu

2. Balteş N., Ciuhureanu A.-T., 2010. Bazele contabilității. Fundamente teoretice şi practice, Publishing House of the „Lucian Blaga” University of Sibiu

3. Balteş N., Ciuhureanu A.-T., 2007. Contabilitate financiară, Publishing House of the „Lucian Blaga" University of Sibiu

4. Brabete V., Drăgan C., 2004. Decapitalizarea companiilor în condiții de inflație sau conflictul contabilitate tradițională - menținerea capitalului, Revista Contabilitatea, expertiza şi auditul afacerilor, no. 7

5. Ciuhureanu A.-T., 2010. Management financiar, Publishing House of the „Lucian Blaga” University of Sibiu

6. Pântea I. P., Bodea Gh., 2011. Contabilitatea financiară, INTELCREDO Publishing House, Deva

7. Ristea M., 2005. Contabilitatea financiară a intreprinderii, Universitară Publishing House, Bucureşti

8. Sandu Gh., 2000. Formarea capitalurilor firmelor private, Economică Publishing House, Bucharest

9. Teulié J., 1996. Analyse financière de l'entreprise, Éditions Dalloz, Paris

10. *** - Standardele Internaționale de Raportare Financiară emise la 1 ianuarie 2011, part A, CECCAR Publishing House, 2011, Bucharest, pp. A50 - A51

11. *** - Law no. 31/1990 regarding commercial enterprises, republished, in Official Gazette no. 1066/17.11.2004, with the following changes

12. The order of the Ministry of the Public Finance no. 3055/2009 for the approval of the Accounting regulations in compliance with the European directives, in Official Gazette no. 766, 766 bis/10.11.2009, with the following changes 